\title{
Phagotrophy and fecal pellet production by an athecate dinoflagellate in Antarctic sea ice
}

\author{
Kurt R. Buck ${ }^{1}$, Patricia A. Bolt ${ }^{2}$, David L. Garrison ${ }^{1}$ \\ ${ }^{1}$ Institute of Marine Sciences, University of California, Santa Cruz, California 95064, USA \\ ${ }^{2}$ Electron Microscope Facility, University of California, Santa Cruz, California 95064, USA
}

\begin{abstract}
A phagotrophic athecate dinoflagellate was found in sea ice and the underlying watercolumn of the Weddell Sea ice edge during the austral autumn of 1986. This organism lacked a sulcus, a cingulum and flagella but possessed a dinokont nucleus, a cytostome and amphiesmal vesicles. Abundances exceeded $10^{5} 1^{-1}$ in the ice. The single large food vacuole contained a variety of protistan prey but was predominantly composed of the pennate diatom Nitzschia cylindrus. The fecal pellet produced upon the egestion of this vacuole was membrane bound. Of the fecal pellet volume $15 \%$ was identifiable protoplasm, mostly $N$. cylindrus. Carbon per pellet averaged $97 \mathrm{pg}$, and abundances of the fecal pellet in the ice also exceeded $10^{5} \mathrm{l}^{-1}$. Release of the fecal pellet into the underlying water column upon melting of the ice may account for a significant proportion of the particulate organic carbon available to metazoan grazers at the ice edge. Flux of material out of the euphotic zone via this fecal pellet may be significant.
\end{abstract}

\section{INTRODUCTION}

Heterotrophic forms comprise approximately one half of the known species of dinoflagellates (Gaines \& Elbrachter 1987) and account for a similar proportion of the abundance of this group in the euphotic zone of many oceanic environments (Lessard \& Swift 1986. Shapiro et al. 1989). Their importance as grazers in marine food webs may surpass that of ciliates due to their higher abundances and higher specific clearance rates (Lessard \& Swift 1985). A variety of feeding methods have been reported, including engulfment of whole prey organisms, evacuation of the protoplasmic contents of prey using a peduncle, or ensnarement of prey organisms in a feeding veil (pallium) followed by extracellular digestion (see Gaines \& Elbrachter 1987 for review). Of these forms of phagotrophy, engulfment is the least well known. Observations have been limited to light microscopy of organisms in the act of ingestion or the presence of food vacuoles inside dinoflagellates.

The majority of organic carbon and opal vertical flux within the euphotic zone and to the deep ocean in the Antarctic is contributed by fecal pellets (Bodungen et al. 1988, Fischer et al. 1988), and a significant proportion of this flux in the euphotic zone is composed of small pellets (30 to $150 \mu \mathrm{m}$ ) (Sasaki \& Hoshiai 1986 ,
Nothig \& Bodungen 1989). The specific sources of these small fecal pellets in Antarctic waters are unknown, although protists (Nothig \& Bodungen 1989) and metazoans (Sasaki \& Hoshiai 1986) have been suggested as the potential producers. Radiolarians, other protists and hydromedusae have been reported as potential producers of small fecal pellets in temperate regions (Gowing \& Silver 1985). Recent evidence from Antarctic studies indicates that dinoflagellates are capable of ingesting large particles (Nothig \& Bodungen 1989) and producing consolidated fecal pellets (Elbrachter in press), so that these protists could have an important role in contributing to vertical flux.

Antarctic sea ice supports high concentrations of bacteria, diatoms, autotrophic flagellates, heterotrophic flagellates, ciliates and metazoans (Garrison in press, Garrison \& Buck 1989a). When released from ice, the fate of ice-bound algae may be an inoculum for the water column phytoplankton (Garrison \& Buck 1985 , Garrison et al. 1987), a food source for ice edge pelagic grazers (Ackley et al. 1979) or a source of carbon and opal flux to the depths (Horner \& Schrader 1982). The abundance and diversity of heterotrophs found associated with sea ice suggests that a significant proportion of the ice-associated biomass may be consumed in situ (Garrison \& Buck 1989a), altering the quantity and nature of the material prior to its release to the water 
column. We present data on the abundance and morphology of an athecate dinoflagellate that feeds by engulfment and produces a membrane-bound fecal pellet that is subsequently released to the water column upon melting.

\section{MATERIALS AND METHODS}

Samples were collected during the austral fall (March 1986) cruise of the Antarctic Marine Ecosystem Research in the Ice Edge Zone (AMERIEZ) program conducted in the Weddell Sea $\left(64\right.$ to $62^{\circ}, 48$ to $52^{\circ} \mathrm{W}$; see Garrison \& Buck 1989a for sampling location). Samples were taken from annual sea ice with a SIPRE ice corer. Samples of the surface layer brine were obtained by removing a $20 \mathrm{~cm}$ core section from the surface of the floe and collecting the ice-free brine that accumulated. To reduce osmotic shock in sections of ice cores (ca $20 \mathrm{~cm}$ in length), they were melted in filtered seawater (Garrison \& Buck 1986). Samples (20 1) of seawater directly under selected ice floes were collected and concentrated through $20 \mu \mathrm{m}$ mesh using a reverse flow technique (Garrison \& Buck 1989b). Additional large volume samples from throughout the upper $100 \mathrm{~m}$ of the water column were also taken and reverse flow concentrated at 3 stations under the ice (see Garrison \& Buck 1989b for these water column station locations). Most samples were preserved with Karnovsky's solution (Gold 1976); however a small volume $(100 \mathrm{ml})$ of selected ice samples was preserved with Bouin's preservative (Coats \& Heinbokel 1982). An Olympus BHS light microscope equipped with epifluorescence (blue excitation) was used aboard ship to examine fresh material for chlorophyll autofluorescence.

Abundance estimates of fecal pellets and their potential producers in ice (unconcentrated) and water column (reverse flow concentrated) samples were made during routine enumerations of all protists using an inverted microscope (Reid 1983). Samples for scanning electron microscopy (SEM) (Bouin's preservative) were osmicated, serially dehydrated to acetone, criticalpoint dried from carbon dioxide and sputter-coated with gold-palladium. Samples for transmission electron microscopy (TEM), which also came from the ice, were osmicated, serially dehydrated and embedded in Spurr's resin. The resin was polymerized in a thin layer from which individual pellets and dinoflagellates were isolated for thin sectioning (Reymond \& Pickett-Heaps 1983). The amount of carbon per pellet was calculated by determining the percent of cross sectional area occupied by prey protoplasm using transmission electron micrographs. This value was multiplied by the volume of the fecal pellet, which we determined with the light microscope, to give the volume of the fecal pellet occupied by identifiable protoplasm. The regression $\log _{10} C(p g)=0.76 \log _{10}\left[\right.$ Cell vol. $\left.\left(\mu m^{3}\right)\right]-0.335$ (Eppley et al. 1970) was used to convert pellet volume to pellet carbon.

\section{RESULTS}

An athecate dinoflagellate with a prominent food vacuole was observed in 8 brine, 4 under-ice and 13 water column samples, and fecal pellets were observed in 3 core sections, 6 brine and 13 water column samples (Table 1). The dinoflagellate was observed in all the samples where fecal pellets were found. Dinoflagellate abundances range from $10^{5} \mathrm{I}^{-1}$ within the ice to $10 \mathrm{I}^{-1}$ in the underlying water column (Table 1). Chlorophyll a concentrations of the ice samples ranged from 0.17 to $14.6 \mu g I^{-1}$. Chlorophyll concentrations in the under-ice and water column were more uniform averaging $0.1 \pm 0.03 \mu \mathrm{g} \mathrm{l}^{-1}$ (Table 1). There was no apparent relationship between abundances of fecal pellets, dinoflagellates or chlorophyll concentrations.

The dinoflagellate is irregularly oval in shape and ca $50 \times 50 \mu \mathrm{m}$ in size (Figs. 1 to 4 ). The shape of the cell in unpreserved brine samples, which were examined live aboard ship, did not differ from that of preserved cells. All cells examined with the light microscope (LM) ( $n=916$, Table 1) contained a large food vacuole which displaced the nucleus toward one end of the cell. Pennate diatoms were observed in the vacuoles of all the dinoflagellates examined. The presence of chlorophyll autofluorescence in the vacuoles of fresh material indicated intact cytoplasm in the diatoms; this was confirmed with TEM. The sulcus, cingulum and flagella typical of dinoflagellates were not seen on any of the specimens prepared for LM or EM. A shallow groove ca $20 \mu \mathrm{m}$ long occurs on one surface of the dinoflagellate (Figs. 2 to 5 ) but no flagella or flagellar pores were associated with this structure. Flagella may have been dropped in preserved samples, although nothing indicative of their presence could be detected in unpreserved samples. Numerous small hexagonal and pentagonal amphiesmal vesicles were found on the surface of the dinoflagellate (Fig. 6). Three specimens were recorded apparently in the act of ingesting prey (Figs. 7 to 12). The oral opening or cytostome is elliptical in shape with a margin defined by swollen labia. The margin of this opening resembled the surface groove seen on other specimens (Fig. 5). An undefined matrix emanating from the oral opening and appearing to ensnare food items may be a pseudopodium (Figs. 9 to 12). This matrix was not observed with living organisms.

Fecal pellets were elliptical to spherical in shape and 
Table 1. Abundances (ind $\left.1^{-1}\right)$ of the sea-ice dinoflagellate, and dinoflagellate fecal pellets and chlorophyll a $\left(\mu g l^{-1}\right)$ concentrations in ice and under-ice samples. $n$ : number of observations made in a particular sample of either dinoflagellates or fecal pellets. Blanks indicate no diroflagellates and/or fecal pellets were found. See Garrison \& Buck (1989b) for location of Stns G12 to G14

\begin{tabular}{|c|c|c|c|c|c|c|}
\hline & & Dinoflagellates & $\mathrm{n}$ & Fecal pellets & $\mathrm{n}$ & Chlorophyll a \\
\hline \multicolumn{2}{|c|}{ Ice cores } & & & $\begin{array}{l}5.2 \times 10^{4} \\
1.3 \times 10^{5} \\
4.8 \times 10^{4}\end{array}$ & $\begin{array}{l}24 \\
55 \\
39\end{array}$ & $\begin{array}{l}1.14 \\
1.71 \\
3.55\end{array}$ \\
\hline \multicolumn{2}{|l|}{ Brine } & $\begin{array}{l}9.1 \times 10^{2} \\
2.4 \times 10^{2} \\
1.2 \times 10^{2} \\
2.0 \times 10^{4} \\
2.4 \times 10^{2} \\
1.0 \times 10^{5} \\
4.2 \times 10^{4} \\
3.2 \times 10^{3}\end{array}$ & $\begin{array}{r}38 \\
2 \\
1 \\
164 \\
6 \\
194 \\
170 \\
16\end{array}$ & $\begin{array}{l}2.5 \times 10^{4} \\
1.8 \times 10^{5} \\
2.0 \times 10^{3} \\
1.4 \times 10^{5} \\
4.2 \times 10^{4} \\
3.6 \times 10^{2}\end{array}$ & $\begin{array}{r}211 \\
\\
\\
48 \\
50 \\
32 \\
174 \\
3\end{array}$ & $\begin{array}{l}0.28 \\
0.13 \\
2.76 \\
1.06 \\
0.17\end{array}$ \\
\hline \multicolumn{7}{|c|}{ Water column ${ }^{a}$} \\
\hline \multicolumn{2}{|c|}{ Under ice } & $\begin{array}{l}5.1 \times 10^{0} \\
8.6 \times 10^{0} \\
1.2 \times 10^{1} \\
3.5 \times 10^{0}\end{array}$ & $\begin{array}{l}13 \\
26 \\
28 \\
15\end{array}$ & & & $\begin{array}{l}0.14 \\
0.08 \\
0.08 \\
0.08\end{array}$ \\
\hline $\mathrm{G} 12$ & $\begin{array}{r}0 \mathrm{~m} \\
15 \mathrm{~m} \\
30 \mathrm{~m} \\
50 \mathrm{~m} \\
75 \mathrm{~m} \\
100 \mathrm{~m}\end{array}$ & $\begin{array}{l}9.2 \times 10^{0} \\
7.2 \times 10^{0} \\
3.6 \times 10^{0}\end{array}$ & $\begin{array}{l}21 \\
19 \\
12\end{array}$ & $\begin{array}{l}8.9 \times 10^{1} \\
2.8 \times 10^{1} \\
6.7 \times 10^{1}\end{array}$ & $\begin{array}{r}235 \\
91 \\
277\end{array}$ & \\
\hline G13 & $\begin{array}{r}0 \mathrm{~m} \\
15 \mathrm{~m} \\
30 \mathrm{~m} \\
50 \mathrm{~m} \\
75 \mathrm{~m} \\
100 \mathrm{~m}\end{array}$ & $\begin{array}{l}8.0 \times 10^{-1} \\
1.8 \times 10^{0} \\
1.1 \times 10^{0} \\
4.0 \times 10^{-1} \\
5.0 \times 10^{-1}\end{array}$ & $\begin{array}{r}4 \\
10 \\
4 \\
2 \\
3\end{array}$ & $\begin{array}{l}6.4 \times 10^{0} \\
1.0 \times 10^{1} \\
1.3 \times 10^{1} \\
4.0 \times 10^{-1} \\
7.7 \times 10^{0}\end{array}$ & $\begin{array}{r}29 \\
57 \\
57 \\
2 \\
51\end{array}$ & \\
\hline G14 & $\begin{array}{r}0 \mathrm{~m} \\
15 \mathrm{~m} \\
30 \mathrm{~m} \\
50 \mathrm{~m} \\
75 \mathrm{~m} \\
100 \mathrm{~m}\end{array}$ & $\begin{array}{l}7.0 \times 10^{0} \\
8.5 \times 10^{0} \\
4.8 \times 10^{0} \\
8.2 \times 10^{0} \\
8.0 \times 10^{0}\end{array}$ & $\begin{array}{l}35 \\
41 \\
\\
20 \\
35 \\
41\end{array}$ & $\begin{array}{l}6.2 \times 10^{0} \\
1.2 \times 10^{1} \\
\\
8.2 \times 10^{0} \\
1.4 \times 10^{1} \\
1.0 \times 10^{1}\end{array}$ & $\begin{array}{l}31 \\
56 \\
\\
34 \\
61 \\
52\end{array}$ & \\
\hline
\end{tabular}

averaged $30 \mu \mathrm{m}$ in diameter (Figs. 13 to 18 ). The shape of the fecal pellet is defined by the contents of the pellet and is surrounded by a membrane. Most of the fecal pellets lacked complete membranes; however, no pellets were observed without some remnant of a membrane. The membranes surrounding the pellet and food vacuoles inside the dinoflagellate are similar in thickness; however, no fine structure in either membrane was evident (Figs. 19 to 22).

The contents of the fecal pellets included pennate and centric diatoms, chrysophyte statospores (archaeomonads), dinoflagellates, Phaeocystis pouchetii, unidentified protists and bacteria (Figs. 21 and 22). Pellets observed in the field with fluorescence microscopy showed red autofluorescence indicative of chlorophyll. The contents of the fecal pellets were similar to those found in the food vacuole of the dinoflagellate (Figs. 9 to 12 and 19 to 22). As many as 20 Nitzschia cylindrus and 12 chrysophyte statospores were observed in single pellets. The relative abundance of prey organisms within the fecal pellets did not reflect the surrounding algal assemblages at the time of sampling. For example, N. cylindrus dominated the fecal pellet contents in 2 ice samples (58\% and $84 \%$ ) but was rare in the ice algal assemblage ( $6 \%$ and $5 \%$ respectively).

Fecal pellet volumes ranged from $1.1 \times 10^{3}$ to $2.3 \times 10^{4} \mu^{3}\left(\right.$ mean $=8.5 \times 10^{3} \pm 7.5 \times 10^{3} \mu^{3}$, $\mathrm{n}=45)$. One to $29 \%($ mean $=15 \pm 11 \%, \mathrm{n}=7)$ of the pellet volume was comprised of recognizable protoplasm (Figs. 21 and 22), almost exclusively made up of 

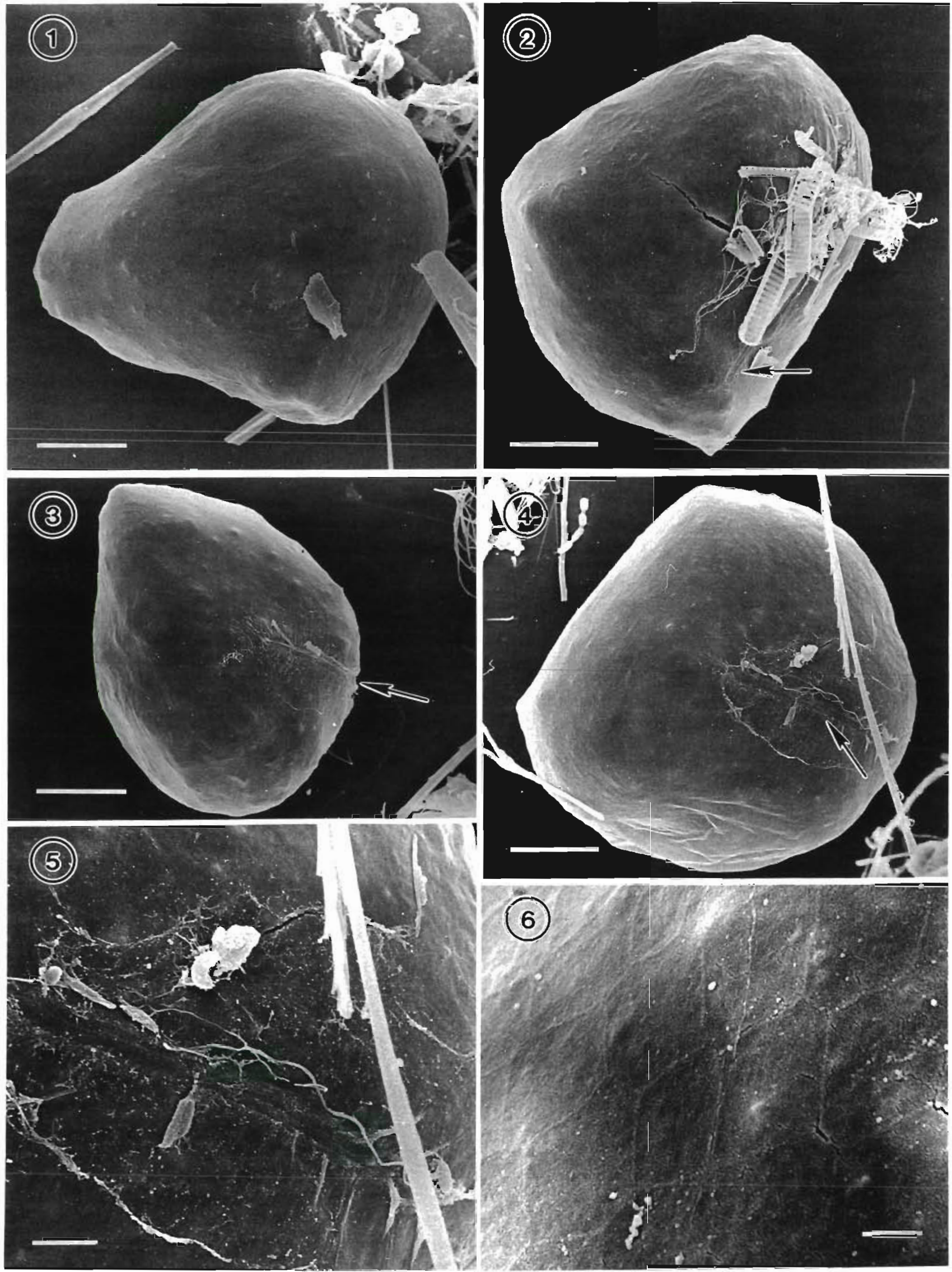

Figs. 1 to 6 . Scanning electron micrographs of critical-point-dried dinoflagellates from sea ice. Figs. 1 to 4 . Intact dinoflagellate cells with cytostome visible in Figs. 2 to 4 (arrows). Fig. 5. High magnification of Fig. 4 showing details of cytostome. Fig.6. Amphiesmal vesicles. Scale bars: Figs. 1 to $4=10 \mu \mathrm{m}$; Fig. $5=2.5 \mu \mathrm{m}$; Fig. $6=1 \mu \mathrm{m}$ 

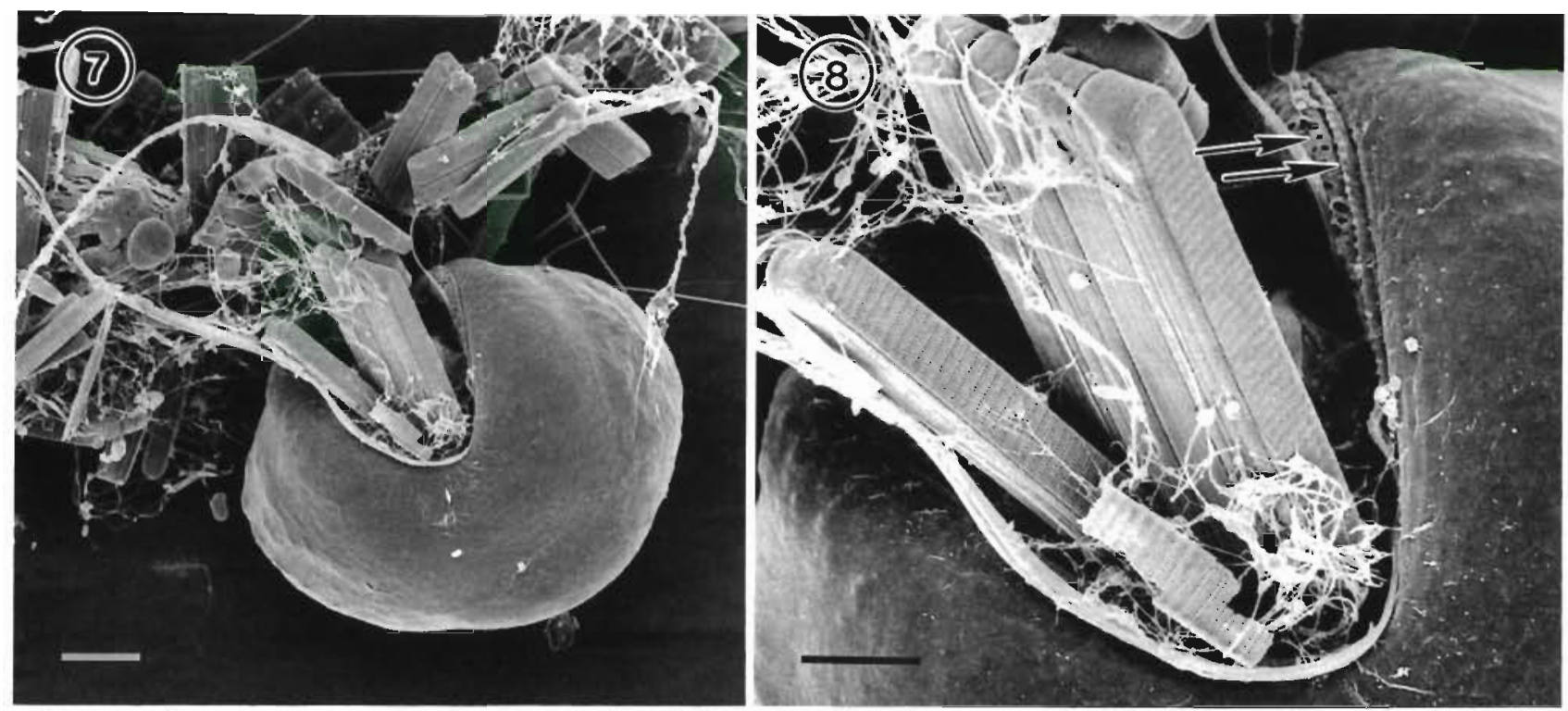

(9)
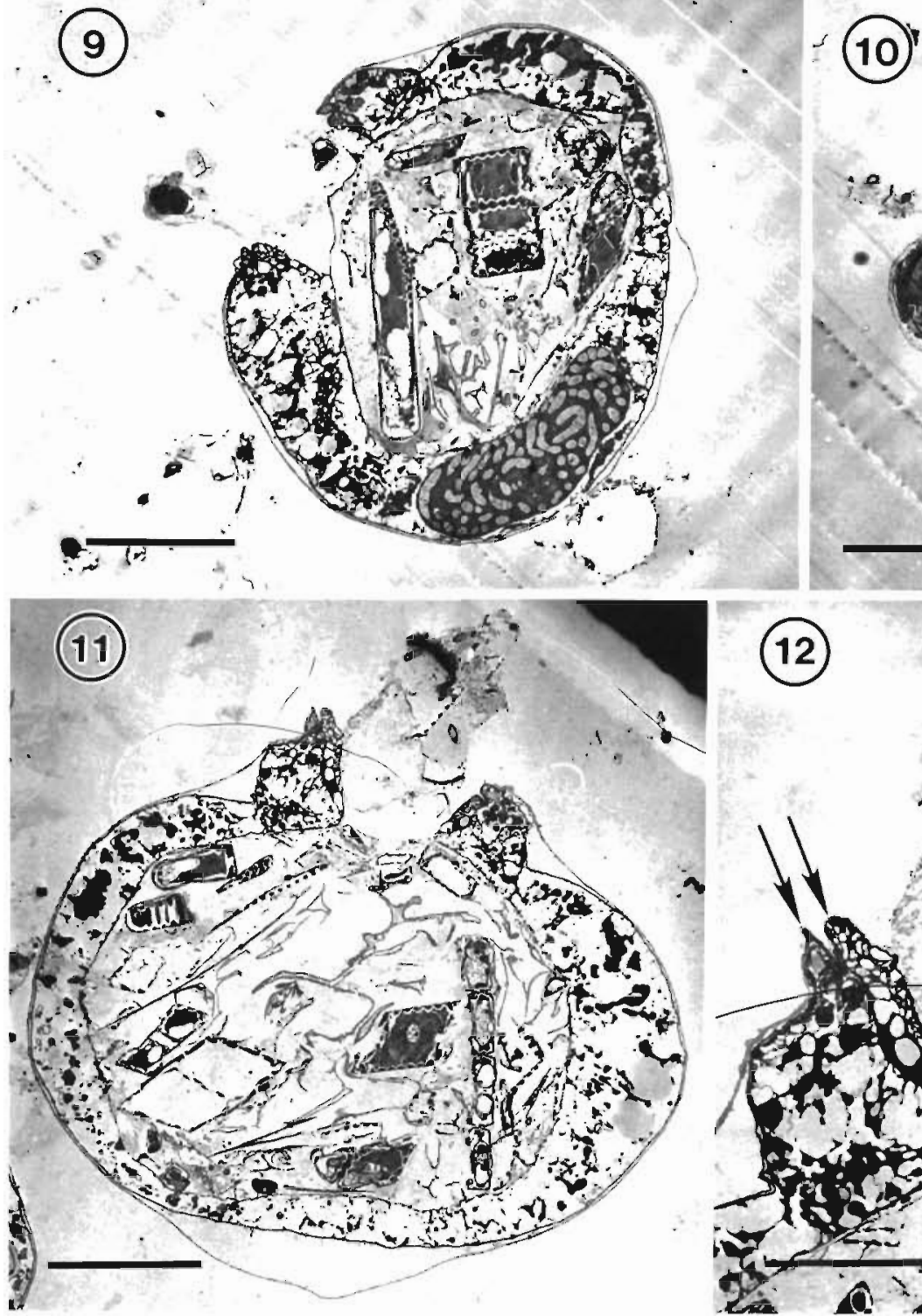

(12)
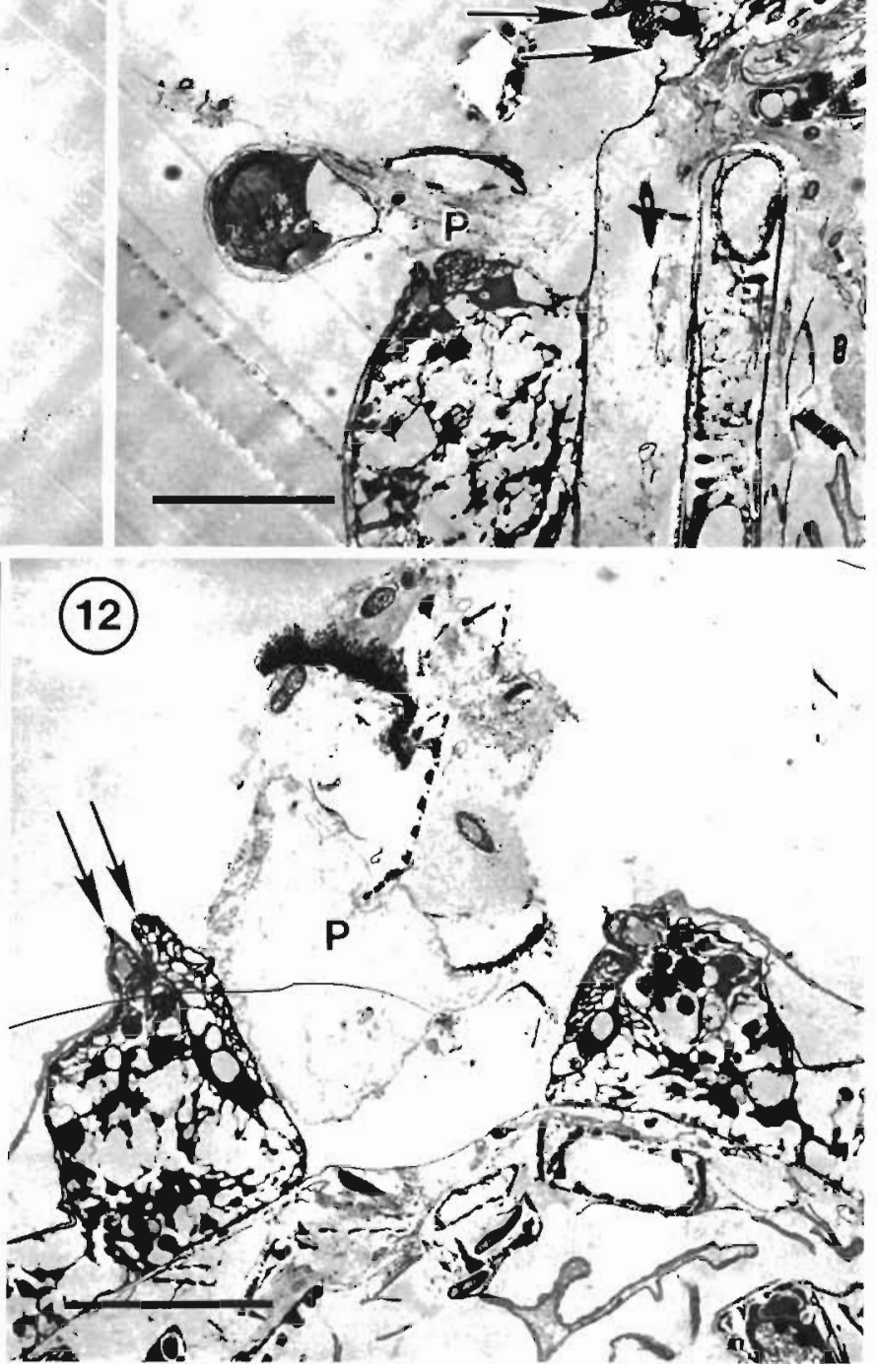

Figs. 7 to 12. Electron micrographs of feeding dinoflagellate. Figs. 7. 8. Scanning electron micrograph of critical-point-dried dinoflagellate ingesting Nitzschia cylindrus. Arrows in Fig.8 denote comparable structures in Figs. 10 \& 12. Figs. 9, 11. Transmission electron micrograph of feeding dinoflagellate showing conspicuous food vacuole containing $N$. cylindrus, dinoflagellate nucleus, and open cytostome. Figs. 10, 12. Transmission electron micrograph showing feeding veil or pseudopodium (P) with ensnared prey items. Arrows denote comparable structures in Fig. 8 . Scale bars: Figs. 7, 9, $11=10 \mu \mathrm{m} ;$ Figs. $8,10,12=5 \mu \mathrm{m}$ 

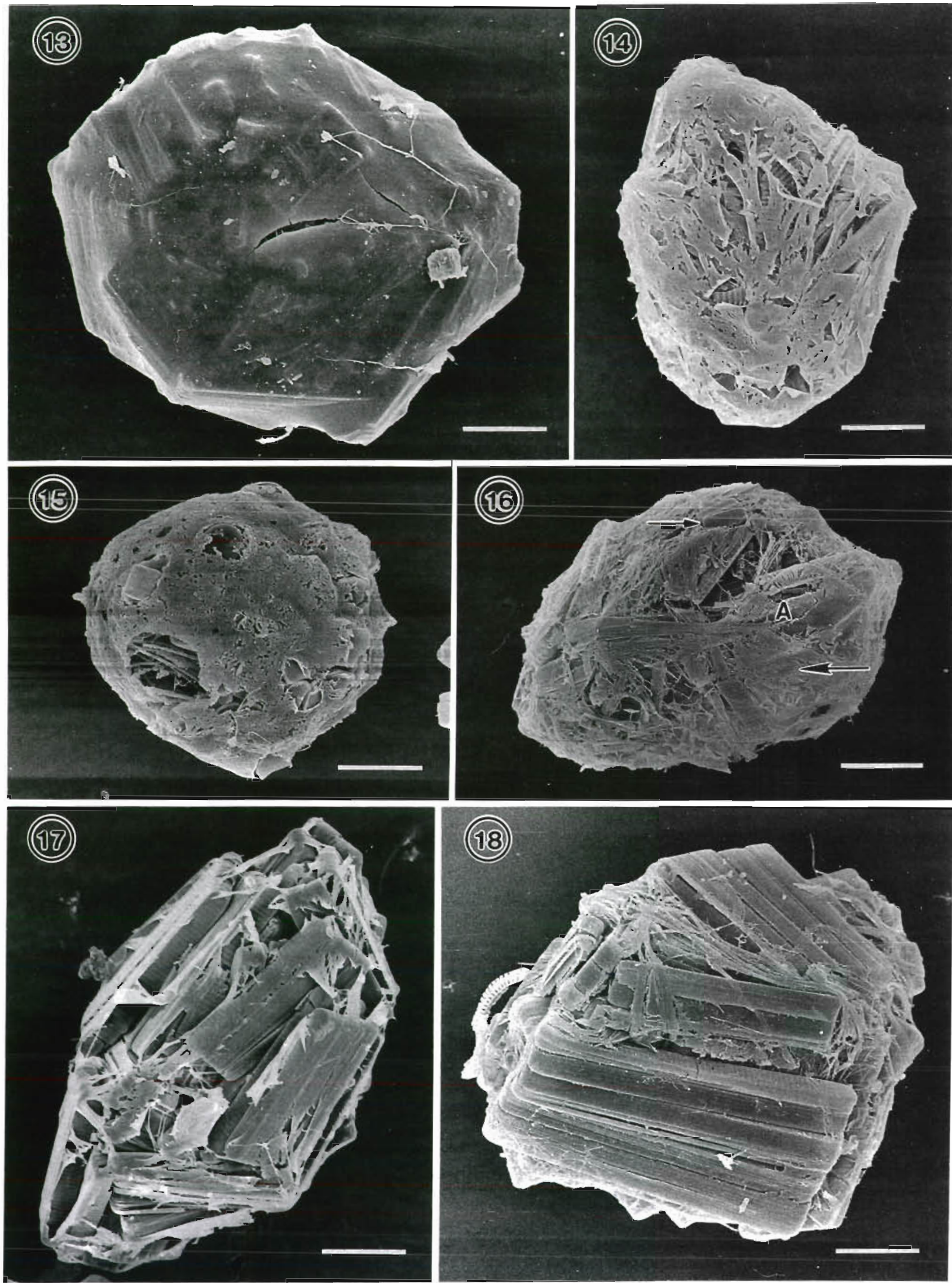

Figs 13 to 18 . Scanning electron micrographs of critıcal-point-dried fecal pellets from sea ice. Fig. 13. Fecal pellet completely covered by membrane. Fig. 14. Fecal pellet, with partial membrane, containing diatom valves. Fig. 15. Fecal pellet, with partial membrane, containing diatoms and other cell parts. Fig. 16. Fecal pellet, with vestige of membrane covering, (arrow) containing Nitzschia cylindrus (small arrow). Amphiprora kjellmanii (A), and dinoflagellate trichocysts. Fig. 17. Fecal pellet, with partial membrane covering, containing $N$. cylindrus. Fig. 18. Fecal pellet. with partal membrane covering, containing $N$. cylindrus. All 


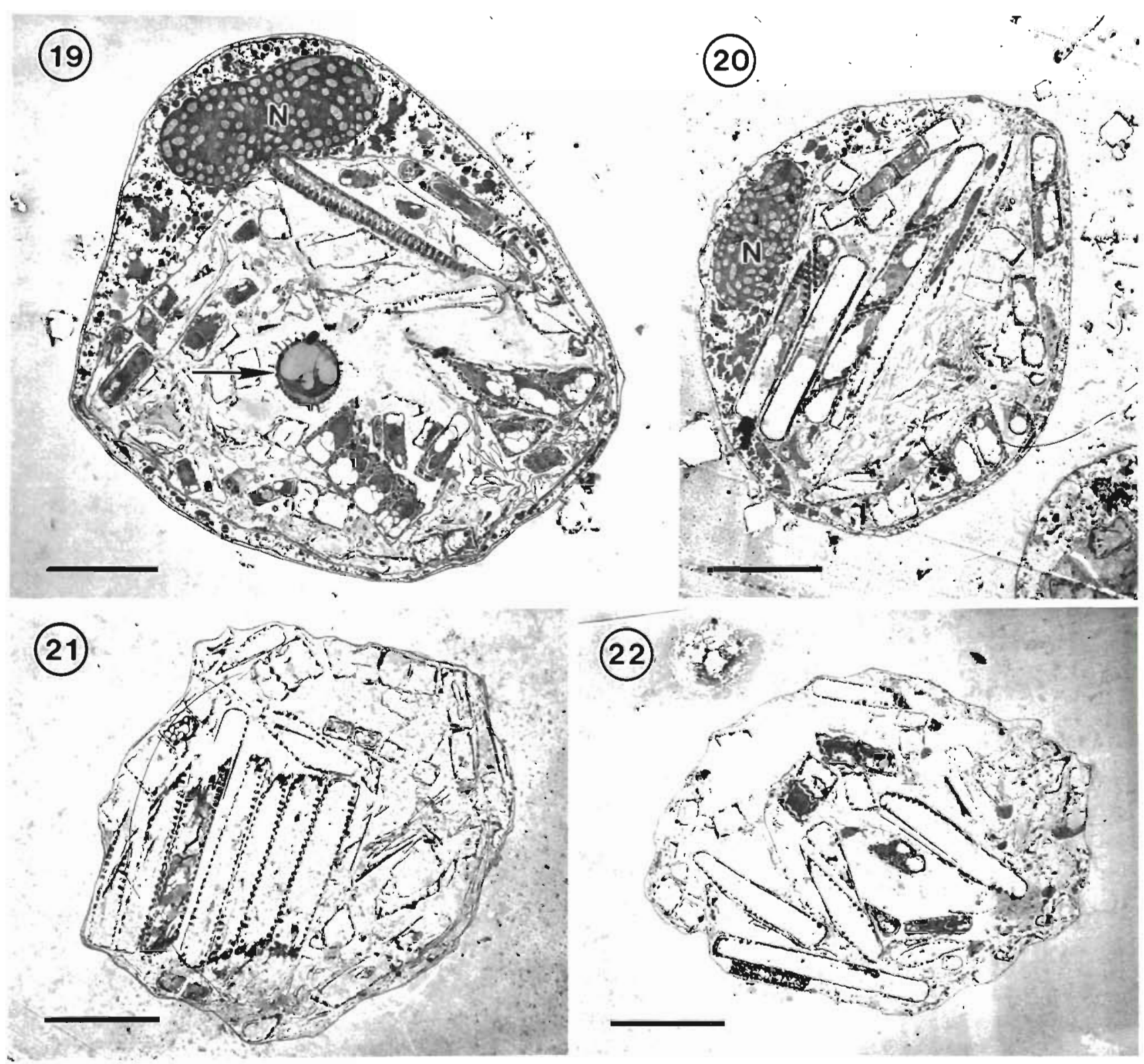

Figs. 19 to 22. Transmission electron micrographs of dinoflagellate and fecal pellet from sea ice. Figs 19, 20. Dinoflagellates with nucleus ( $N$ ) and conspicuous food vacuole surrounded by a complete membrane. Arrow denotes a statospore (archaeomonad). Figs.21. 22. Dinoflagellate fecal pellets, surrounded by a complete membrane, containing Nitzschia cylindrus. All scale bars = $10 \mu \mathrm{m}$

Nitzschia cylindrus; the rest of the volume consisted of empty diatom valves and statospores. Carbon per pellet for the mean pellet volume was $96.7 \mathrm{pg}$ (range 20.4 to $206.1 \mathrm{pgC}$ pellet $^{-1}$ ). Abundances of these small fecal pellets ranged from 0 to $1.8 \times 10^{5} \mathrm{l}^{-1}$ (Table 1). Maximum carbon associated with these fecal pellets in the ice was $17 \mu \mathrm{g} \mathrm{l}^{-1}$. Fecal pellet concentrations in the water column ranged from 0.4 to $901^{-1}$ with maximum concentrations occurring at the ice edge station (Table 1).

\section{DISCUSSION}

The presence of intracellular food bodies has been reported in more than 150 dinoflagellate taxa and was the earliest indication that some members of this group are capable of heterotrophic nutrition (Gaines \& Elbrachter 1987). Few of these studies described how dinoflagellates are able to engulf large prey organisms. Noctiluca, a large (ca $0.5 \mathrm{~mm}$ ) athecate obligate heterotroph, has been well studied with both electron 
microscopy (Lucas 1982, Nawata \& Sibaoka 1983) and microcinematography (Uhlig 1972). Noctiluca possesses specialized structures (e.g. tentacle 'tooth', oral pouch, and cytostome) for engulfing its prey. The cytostome of the athecate dinoflagellate from the sea ice may be a simpler structure specialized for ingestion; however, until this can be studied with live dinoflagellates, the feeding mechanisms will remain unknown. Other similarities in morphology between the sea-ice dinoflagellate and Noctiluca include the absence of a sulcus and longitudinal flagellum, and the presence of numerous small amphiesmal vesicles. Based on the ultrastructure of the flagellum present in the oral groove of $N$. scintillans, Lucas (1982) contended that the groove was homologous to the cingulum. The absence of a flagellum in the groove of the sea-ice dinoflagellate prevents us from establishing this homology.

We have established the link between the sea-ice dinoflagellate and the distinctive membrane-bound fecal pellet based upon similarities in size, content, shape and membrane structure (or lack thereof) of the food vacuole and the fecal pellet. Where both dinoflagellates and fecal pellets occurred in high abundances in ice samples, there was little doubt that the phagotrophic dinoflagellate was the source of the fecal pellets. We believe that similar fecal pellets in ice samples, where the phagotrophic dinoflagellate was rare, and fecal pellets in water samples were also produced by the dinoflagellate we describe, although this cannot be unequivocally established.

The fecal pellet produced by this organism is bound by a continuous sheet of refractive material that we have chosen to call a membrane in keeping with the terminology of metazoan fecal pellets (Turner \& Ferrante 1979). The presence of a membrane around fecal pellets is important because it may affect both the rate at which material in the pellet is recycled and remineralized (Turner \& Ferrante 1979, Gowing \& Silver 1983) and also the rate at which the pellet will sink upon release to the water column (Small et al. 1979). Although all heterotrophic protists that feed phagotrophically must produce feces, most reports do not describe a membrane around the feces (Lee et al. 1988 have reported the production of membrane-bound fecal pellets by Foraminifera) or they state that the faeces are unconsolidated (e.g. Stoecker 1984). The mechanism for egestion of a membrane-bound fecal pellet by a protist is not obvious, particularly if the membrane surrounding the fecal pellet is indeed the same as that surrounding the food vacuole. There would have to be some means of egesting such a large particle that would allow the dinoflagellate to maintain its integrity The lack of ultrastructural detail in the membrane covering the pellet and surrounding the food vacuole prevents us from addressing this question.
However, if cell division coincides with the egestion of the pellet, then cytokinesis might provide a means for conserving protoplasm while ridding the cell of the fecal pellet.

We interpret the integrity of the membrane on the fecal pellet to reflect the approximate age of the pellet. The annual ice from which these samples came (ca $1 \mathrm{~m}$ thick) could have been as old as $12 \mathrm{mo}$, and although little is known of the natural history of the ice community, the pellets may have been as old as the ice. Fecal pellets apparently accumulate in ice over time and this may explain why there were pellets found in some samples with no dinoflagellates (Table 1), and why the contents of the pellets did not reflect the algal assemblage at the time of sampling.

The composition of the pellets appears to reflect the prey of the dinoflagellate, although organisms with hard body parts might be over-represented. The preponderance of Nitzschia cylindrus in the fecal pellets is not surprising, since it is one of the most abundant diatoms in ice assemblages (Garrison \& Buck 1985, 1989a, Garison et al. 1987). However, some selection for this prey item may have occurred. Preference for diatoms as food sources has been reported for species of Protoperidinium (Jacobson \& Anderson 1986). The abundance of both the dinoflagellate and its fecal pellets is evidence that some of the primary production within the sea ice is grazed, with the fecal pellets accumulating until they are released to the water column.

Some small fecal pellets, called minipellets, which are thought to be produced by detritivorous protists such as phaeodarians, do have a surrounding membrane (e.g. the 'boundary' described by Gowing \& Silver 1985). However, this is the first report of dinoflagellates producing such a fecal pellet. A difference between the fecal pellet produced by this dinoflagellate and the minipellets is the condition of their contents and how this determines the shape of the pellet. Minipellets are composed of many small refractive and largely unidentifiable cell remains (Gowing \& Silver 1985) and the relatively regular outline of the pellet reflects this. The pellet of protistan herbivores such as this dinoflagellate, which cannot alter the shape of the diatoms it engulfs, will be composed of relatively few and intact cell parts. Therefore, shape, and to some extent size, of the fecal pellets is largely defined by their contents. This accounts for some of the morphological diversity in the fecal pellets we found in the ice and may be a strong argument for assigning small irregularly shaped fecal pellets with undeformed contents to protistan origins (e.g. Nothig \& Bodungen 1989).

Determination of carbon content for small fecal pellets has not been done because of the difficulty of separating pellets from a sample for carbon measurements. Indirect estimates can be made by employing a 
technique similar to the one we used (e.g. 'living carbon' estimated by Gowing \& Silver 1985) or by using other volume: carbon relationships based upon small metazoan fecal pellets which have been measured directly (Small et al. 1983). Our carbon estimate (carbon pellet ${ }^{-1}$ ) is 4 times lower than those derived from the volume carbon relationship for small zooplankton pellets (Small et al. 1983). Gowing \& Silver (1985) reported estimates of 'living carbon' for minipellets that ranged from 0.003 to 0.025 of the carbon values calculated from the volume: carbon regression of Small et al. (1983). Some of this discrepancy is the result of the small amount of recognizable protoplasm $(<1 \%)$, and hence carbon, comprising minipellets. Fecal pellets from the sea-ice dinoflagellate are of a size encompassed by the size range given for minipellets, however content condition, shape and carbon per pellet are all different.

Particulate organic carbon flux in the southeastern Weddell Sea in February 1985 ranged from 15 to 135 $($ mean $=58) \mathrm{mg} \mathrm{m}^{-2} \mathrm{~d}^{-1}$ at depths of 80,100 and $350 \mathrm{~m}$ (Bodungen et al. 1988). This flux was dominated by small ( $<300 \mu \mathrm{m}$ diameter) fecal pellets; an average of $34 \%$ of the volume of this fraction of the flux was composed of fecal pellets less than $150 \mu \mathrm{m}$ (most less than $100 \mu \mathrm{m}$ ) in diameter (Nothig \& Bodungen 1989). The concentration of dinoflagellate fecal pellets we found associated with the water column (mean = $15 \pm 14 \mathrm{1}^{-1}$; Table 1) was not significantly different from the concentration of small fecal pellets found by Nothig \& Bodungen (1989) (means $=68 \pm 52$ and $26 \pm 231^{-1}$ ) in 1985. Although we did not measure the flux in our study, we speculate that dinoflagellate fecal pellets comprise a large proportion of these small fecal pellets and hence flux within the upper water column. During the austral spring and summer, when the ice is actively retreating, we would expect that the contribution to flux by these fecal pellets would increase for a short duration in the vicinity of the ice edge.

Small fecal pellets, including dinoflagellate pellets, may also be important because of the role they play in the redistribution, recycling and remineralization of organic carbon and inorganic nutrients in the upper water column, as suggested by Small et al. (1979) for small metazoan fecal pellets. The carbon of dinoflagellate fecal pellets comprises a relatively small proportion $(<1$ to $10 \%$ ) of the POC (particulate organic carbon) within the sea ice (authors' unpubl. data). However, their size and membrane-bound nature presumably would cause them to sink rapidly relative to ice algae, potentially comprising a significant food source for larger grazers in the lower euphotic zone. Gowing (1989) has shown that phaeodarians, a group of detrivores, have an abundance maxima between 100 and $200 \mathrm{~m}$. Re-ingestion and repackaging by grazers such as these would provide a mechanism for transport of small fecal pellets to deeper water.

In summary, the sea-ice dinoflagellate has a unique morphology and presumably a matching novel feeding behavior. The dinoflagellate is capable of ingesting and repackaging significant proportions of the iceassociated biomass into membrane-bound fecal pellets which may be important to the trophodynamics of the underlying water column as well as of the ice itself. These fecal pellets are fundamentally different from other small fecal pellets (e.g. minipellets) in their morphology, the condition of their contents and the amount of carbon they possess. Taxonomic characterization of the dinoflagellate and questions concerning the actual processes of ingestion and egestion still need to be addressed.

Acknowledgements. We thank $\mathrm{S}$. Coale who prepared the TEM samples and H. Marchant who sectioned some of the fecal pellets. M. Elbrachter, M. Gowing, D. Jacobson, E. Nothig, C. Pilskaln, H. Thomsen and J. Turner provided valuable comments. W Smith provided water column chlorophyll data. This work was supported by a National Science Foundation grant (DPP 8420181) to D. L. G.

\section{LITERATURE CITED}

Ackley, S. F., Buck, K. R., Taguchi, S. (1979). Standing crop of algae in the sea ice of the Weddell Sea region. Deep Sea Res. 26A: 269-281

Bodungen, B. von, Nothig, E.-M., Sui, Q. (1988). New production of phytoplankton and sedimentation during summer 1985 in the southeastern Weddell Sea. Comp. Biochem. Physiol 90B: 475-487

Coats, D. W., \& Heinbokel, J. F. (1982). A study of reproduction and other life cycle phenomena in planktonic protists using an acridine orange fluorescence technique. Mar. Biol. 67 : 71-79

Elbrachter, M. (in press). Faeces production by dinoflagellates and other small flagellates. Microbial Ecol.

Eppley, R. W., Reid, F. M. H., Strickland, J. D. H. (1970). Estimates of phytoplankton crop size, growth rate, and primary production. In: Strickland, J. D. R. (ed.) The ecology of the plankton off La Jolla, California in the period April through September, 1967. Bull. Scripps. Inst. Oceanogr. 17: 33-42

Fischer, G., Futterer, D., Gersonde, R., Honjo, S., Wefer, Osterman (1988). Seasonal variability of particle flux in the Weddell Sea and its relationship to ice cover. Nature, Lond. 225: 426-428

Gaines, G., Taylor, F. J. R. (1984). Extracellular digestion in marine dinoflagellates. J. Plankton Res. 6: 1057-1061

Gaines, G., Elbrachter, M. (1987), Heterotrophic nutrition. In: Taylor, F. J. R. (ed.) The biology of dinoflagellates. Blackwell Scientific, Oxford, p. 224-268

Garrison, D. L. (in press). Antarctic sea ice biota. Am. Zool

Garrison, D. L., Buck, K. R. (1985). Sea-ice algal communities in the Weddell Sea: species composition in ice and planktonic assemblages. In: Gray, J. S., Christiansen, M. E. (eds.) Marine biology of polar regions and stress on marine organisms. John-Wiley, New York, p. 103-122

Garrison, D. L., Buck, K. R. (1986). Organism losses during ice 
melting: a serious bias in sea ice community studies. Polar Biol. 6: 237-239

Garrison, D. L., Buck, K. R. (1989a). The biota of Antarctic pack ice in the Weddell Sea and Antarctic peninsula regions. Polar Biol. 10 (in press)

Garrison, D. L., Buck, K. R. (1989b). Protozooplankton in the Weddell Sea, Antarctica: abundance and distribution in the ice-edge zone. Polar Biol. 9; 341-351

Garrison, D. L., Buck, K. R., Fryxell, G. A. (1987). Algal assemblages in Antarctic pack ice and in ice-edge plankton. J. Phycol. 23: 564-572

Gold, K. (1976). Methods for preserving Tintinnida. In: Steedman, H. F. (cd.) Zooplankton fixation and preservation. UNESCO, Paris, p. 236-239

Gowing, M. M. (1989). Abundance and feeding ecology of Antarctic phaeodarian radiolarians. Mar. Biol. 103: $107-118$

Gowing, M. M., Silver. M. W (1983). Origins and microenviromments of bacteria mediating fecal pellet decomposition in the sea. Mar. Biol. 73: 7-16

Gowing, M. M., Silver, M. W (1985). Minipellets: a new and abundant size class of marine fecal pellets. J. mar. Res. 43 $395-418$

Horner, R. A., Schrader, G. C. (1982). Relative contribution of lce algae, phytoplankton, and benthic microalgae to primary production in nearshore regions of the Beaufort Sea. Arctic 35: 485-503

Jacobson, D. M., Anderson, D. M. (1986). Thecate heterotrophic dinoflagellates: feeding behavior and mechanisms. J. Phycol. 22: 249-258

Lee, J. J., Erez, J., ter Kuile, B., Logziel, A., Burgos, S. (1988). Feeding rates of two species of larger foraminifera Amphistegnia lobifera and Amphisorus hemprichil from the Gulf of Eliat (Red Sea). Symbiosis 5: 61-102

Lessard, E. J., Swift, E. (1985). Species-specific grazing rates of heterotrophic dinoflagellates in oceanic waters, measured with a dual-lable radioisotope technique. Mar Biol. 87: $289-296$

This article was presented by Dr D. K. Stoecker, Woods Hole, Massachusetts, USA
Lessard. E. J., Swift, E. (1986). Dinoflagellates from the North Atlantic classifued as phototrophic or heterotrophic with epifluorescence microscopy. J. Plankton Res. 8: 1209-1215

Lucas, 1. A. N. (1982). Observations on Voctiluca scintillans (Macartney) Ehrenb. (Dinophyceae) with notes on an intercellular bacteria. J. Plankton Res. 4: 401-409

Nawata, T. Sibaoka, T (1983). Experimental induction of feeding behavior in Noctiluca miliaris. Protoplasma 115: 34-42

Nothig, E.-M., Bodungen, B. von (1989). Occurrence and vertical flux of faecal pellets of probably protozoan origin in the southeastern Weddell Sea (Antarctica). Mar Ecol. Prog. Ser 56: 281-289

Reid, F. M. H. (1983). Biomass estimation of components of marine nanoplankton and picoplankton by the Utermohl method. J. Plankton Res. 5: 235-251

Reymond, O. L., Pickett-Heaps, J. D. (1983). A routine flat embedding method for electron microscopy of microorganisms allowing selection and precisely orientated sectioning of cells. J. Microsc. 1.30: 79-84

Sasaki, H., Hoshiai, T (1986). Sedimentation of microalgae under the Antarctic fast ice in summer. Mem. Natl. Inst. Polar Res., Spec. Issue, 40: 45-55

Shapiro, L. P., Haugen, E. M., Carpenter, E J. (1989). Occurrence and abundance of green-fluorescing dinoflagellates in surface waters of the Northern Allantic and Northwest Pacific Oceans. J. Phycol. 25: 189-191

Small, L. F., Fowler, S. W., Moore, S. A., LaRosa, J. (1983). Dissolved and fecal pellet carbon and nitrogen release by zooplankton in tropical waters. Deep Sea Res. 30 . $1199-1220$

Small, L. F., Fowler, S. W., Onlu, M. Y (1979). Sinking rates of natural copepod fecal pellets. Mar Biol. 51·233-241

Stoecker, D. K. (1984). Particle production by planktontc ciliates. Limnol. Oceanogr. 29: 930-940

Turner, J. T., Ferrante, J. G. (1979). Zooplankton fecal pellets in aquatic ecosystems. BioScience 29: 670-677

Uhlig, G. (1972). Entwicklung von Noctiluca miliaris. Inst. wiss. Film $\mathrm{C}$ 879:1-15

Manuscript first received: September 15, 1989

Revised version accepted: November 14, 1989 